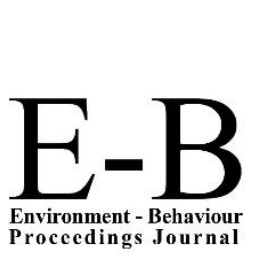

\section{ASLI QoL 2017

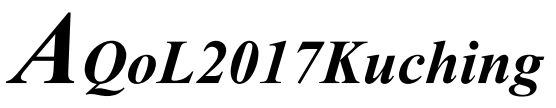 \\ http://www.amerabra.org; https://fspu.uitm.edu.my/cebs $3^{\text {rd }}$ ABRA International Conference on Quality of Life "Quality of Life 3"}

Riverside Majestic Hotel, Kuching, Malaysia, 14-16 Oct 2017

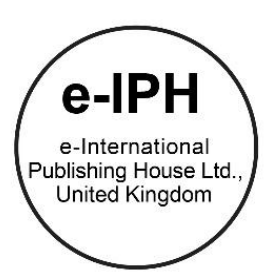

\title{
Measuring Service Quality Expectation and Satisfaction Using Servqual at Hutan Lipur Sungai Congkak
}

\author{
Nur Idzhainee Hashim, Norajlin Jaini, Ely Rouzee Jamaluddin , Firdaus Chek Sulaiman \\ Centre of Studies for Park and Amenity Management, Faculty of Architecture, Planning and Surveying, \\ Universiti Teknologi Mara, 40450 Shah Alam, Selangor. \\ nuridzhaineehashim@gmail.com \\ Tel : 018-902 4100
}

\begin{abstract}
Recreation activity based on recreational forest has risen as one of the important industries in the Malaysia economy. This area has a great potential for future development predominantly in this modern trend where people are more concern about living a healthy lifestyle and being close to nature. The purpose of this paper is to obtain a better understanding of the extent to which service quality is delivered within Hutan Lipur Sungai Congkak. This study searched the influence of service quality attributes on expectation and satisfaction of recreational forest based on SERVQUAL model. The finding shows that service quality directly impacted visitors' satisfaction on the five aspects of service quality. Hence, the results of this study provide important theoretical implications for nature-based tourism managers.
\end{abstract}

Keywords: Recreational Forest, Service Quality, Recreation, Visitors Satisfaction

eISSN: 2398-4287C 2017. The Authors. Published for AMER ABRA by e-International Publishing House, Ltd., UK. This is an open access article under the CC BYNCND license (http://creativecommons.org/licenses/by-nc-nd/4.0/). Peer-review under responsibility of AMER (Association of Malaysian Environment-Behaviour Researchers), ABRA (Association of Behavioural Researchers on Asians) and cE-Bs (Centre for Environment-Behaviour Studies), Faculty of Architecture, Planning \& Surveying, Universiti Teknologi MARA, Malaysia.

https://doi.org/10.21834/e-bpj.v2i6.858

\subsection{Introduction}

Recreation activity based on nature recreational forest has risen as one of the important industries in Malaysia economy since the last several decades. This area has a great potential for future development predominantly in this modern trend where people are more concern about living a healthy and dynamic lifestyle and being close to nature. Nature recreational forest is an outdoor recreation space for the health recreational and natural education which also recognized as a green belt located in the places with high recreation value inside the city or suburbs (Man- Su Kang, 2015). A better understanding of the quality of service at nature recreational forest area is considered a crucial factor to enhance tourism success and is likely to ensure satisfaction among visitors and possibility of getting return visits. The expansion in recreational needs increased due to rising number of the populace, familiarity with relaxation and currency, and upward pattern in nature appreciation (Yahha, 1999). Since the success of a recreational forest is dependent upon the quality of the participants' experiences, park providers must know how the visitors define service quality. At present, recreational forest development represents a significant shift where it changed from providing space for recreational activities to domestic and international tourism due to its ability to support the development of tourism industry (Mohd Kher, 2009). Various standards and guidelines have been submitted from every agency to ensure service quality at recreational forest area will continue to overgrow such as in natural resources management, wildlife, facilities, and infrastructure. Visitor perception towards service in the recreational forest is one of the factors to attract local and foreign tourist to support the recreation area. According to Love (1995), service quality is important in any business involving the recreational forest-based ecotourism as it helps to create a bond between businesses and

eISSN: 2398-4287@ 2017. The Authors. Published for AMER ABRA by e-International Publishing House, Ltd., UK. This is an open access article under the CC BYNCND license (http://creativecommons.org/licenses/by-nc-nd/4.0/). Peer-review under responsibility of AMER (Association of Malaysian Environment-Behaviour Researchers), ABRA (Association of Behavioural Researchers on Asians) and cE-Bs (Centre for Environment-Behaviour Studies), Faculty of Architecture, Planning \& Surveying, Universiti Teknologi MARA, Malaysia.

https://doi.org/10.21834/e-bpj.v2i6.858 
customers. Previous research proved that service quality has lots of impacts that showed positives and significant relationship between service quality and visitor's satisfaction (Alhamadani \& Mohamad, 2011, Navaratnaseelan \& Elangkumaran, 2014).

In this research two objectives were identified: (i) to identify the visitors' expectation concerning on service quality and (ii) to determine visitors' satisfaction of service quality at Hutan Lipur Sungai Congkak.

\subsection{Literature Reviews}

\subsection{Service quality}

Service quality is a crucial issue for organizational growth and influencing success which is also a significant strategic importance matter for management (Sahny et al., 2006). According to Atafar and SHafiee (2006), service quality is a form of attitude towards satisfaction and is by comparing customer's expectations from services performances. Zeithaml \& Bitner (2006) mentioned service quality as a comparison of what the customers feel a service provider should offer (expectations). Satisfaction is a positive response from the visitors resulting from an expectable experience whereas expectations reflect what an individual anticipates the service to deliver. Satisfaction is an important measure in marketing or evaluating services since it stems from the belief that users who are highly satisfied would likely repeat and become loyal users. Schiffman and Kanuk (2007) stated that "The most widely accepted framework for researching service quality stems from the premise are a function of the magnitude and direction of the gap between customer's expectation of duty and the visitor's assessment on perception of the service delivered". In this research study, SERVQUAL model by Parasuraman (1985) was used as the instrument for measuring service quality and had introduced to the recreation management field by MacKay and Crompton (1988), and Crompton and MacKay (1990). It was considered by Mackay \& Crompton (1988), achieving customer satisfaction is less difficult in a recreation when managers understand their visitor's expectations and satisfaction level of each dimension. Visitor's belief and opinion is crucial for companies seeking to evaluate service quality and measure their satisfaction matters (Baker and Crompton, 2000).

The dimensions consisted of few aspects which are tangible, reliability, assurance, responsiveness, and empathy (Table 1) to measure service quality in the environment in which service quality is considered as necessary to understand visitors. The five dimensions of service quality were derived which is to judge about a service after consumption by the visitors (Jamal \& Naseer, 2002). Tangible represents the environment of the company and how the working staff appears to be (Parasuraman et al., 1988) such as the physical facilities, equipment and appearance of personnel. Reliability was known as the ability to provide the guaranteed service which comprised of reliable and accurate. Zeithaml et al., (2006) had portrayed that reliability as the capacity to play out the guaranteed benefit reliably precisely. Blose \& Tankersky (2004) expressed that reliability is a key measurement between what the provider guarantees. The ability to serve customers is dependably (Parasuraman et al., 1988) through the service they provide in order to satisfy their needs. Assurance is the mindfulness and politeness of workers and their capacity to express trust and certainty. It is also the ability to work out to do successful correspondences when managing customers (Zeithaml et al., 2006). It makes visitors feel safe and easy around the company's environment by having sufficient direction given to visitors at all viewpoints (Yeo, 2008). Responsiveness is the brief provided by the service provider or willing to help users to fulfil their needs and desires. It incorporates the capacity to enhance and polished skill. According to Zeithaml et al., (2006), responsiveness is the ability of workers to help customers in giving their service and ability to respond, and the response speed assumes an essential part. A company feel safe and easy around the enterprise's environment (Parasuraman et al., 1988). The empathy dimension portrays the supplier's readiness and capacity to react to visitor's needs (Bruhn and Georgi, 2006) including the ability to understand their necessities (Parasuraman et al., 1988 ) by offering caring, individualized attention to users.

Table 1. Aspects of service quality

\begin{tabular}{ll}
\multicolumn{1}{c}{ Table 1. Aspects of service quality } \\
\hline Dimension & Aspects \\
\hline Tangible & - The physical facilities and equipment are visually aligned and good condition \\
& - Adequation centre gives relevant information \\
& - Accessibility of physical facilities and natural resources \\
& - Peat appearance of the provk's staff \\
& - Considered needs of disabled \\
\hline Reliability & - Staff providing service with punctual \\
& - Staff provide a promptly efficient and timely \\
& - Staf providing accurate and correct information \\
\hline Assurance & - Tourist feels safe and secure \\
& - The staff is consistently friendly with tourists \\
& - Staff has the knowledge to answer questions \\
\hline Responsiveness to assist tourist in all aspect & - Staff willing to respond to tourist's curiosity \\
& - Staff inform tourist of the exact services and products offered \\
\hline Empathy & - Staff give the tourist personal attention \\
& - Staff understand the tourist's specific needs \\
&
\end{tabular}


- Adequate water supply

- Provide praying spaces

- Comfortable facilities provided

(Source: Parasuraman, 1985)

Figure 1 presents the conceptual research model for service quality assessment. SERVQUAL model is a multi - dimensional research instrument, designed to capture visitor's expectations and perceptions of a service along the five dimensions that are believed to represent service quality. Servqual constructed on the expectancy disconfirmation paradigm, which in simple terms means that service quality is understood as the extent to which consumers pre - consumption expectations of quality are confirmed or disconfirmed by their actual perceptions of the service experience. Service quality is indicated as the arithmetic differences between visitor expectations and perceptions of an area performance. The study has focused on the gap between expectations and perceptions is called a "service quality gap" (Table 2) which referred to "perceived service quality'. The visitor gap is the most critical and fulfilling the most important missions require in a recreational forest. It measures the distance between visitor's initial expectation and final service's perception.

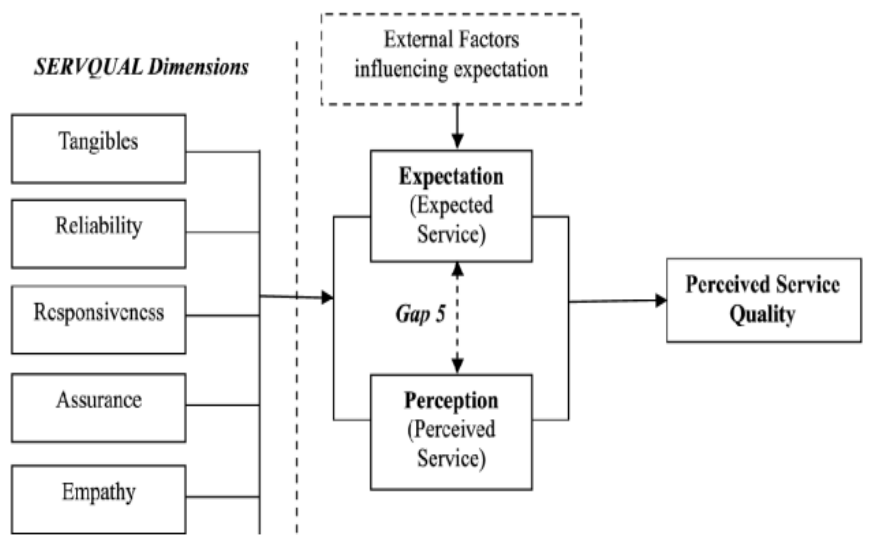

Fig. 1: Parasuraman, Zeithaml \& Berrys Model (Source: Parasuraman et al., 1988)

Table 2. Perceived service quality from the visitor's point of view is often different from expected service quality

\begin{tabular}{ll}
\hline \multicolumn{2}{c}{ Expectations versus Satisfaction Quality } \\
\hline Expectations $<$ Satisfaction on Service Quality & Quality surprise \\
Expectations $=$ Satisfaction Service Quality & Satisfactory quality \\
Expectations $>$ Satisfaction Service Quality & Unacceptable quality \\
\hline
\end{tabular}

(Source: Parasuraman et al., 1985; Parasuraman et al., 1988., Zeithaml et al., 1993)

\subsection{Recreational forest}

Recreational forest in Peninsular Malaysia has been established by the Forestry Department of Peninsular Malaysia for sustainable use maintaining its potential to meet the needs and aspirations since 1965. The recreational forest is an area with environmental values to cater visitors to enjoy the natural environment while helping to create harmony between people of all races. It is a place to meet the preferences of visitors to enjoy the natural surroundings, as well as to create harmony and to meet the needs of various audience. According to Forestry Manual Volume III (2003) defined the area within the Forest Recreation Permanent Reserved Forests (PRF) also provides recreational facilities such as rest, exercise, conduct research and education, and preserve flora and fauna. It is intensively developed for economy benefits as well as for the achieving quality of life through activities within. Recreation forest areas are priority places for the conservation of ecological systems and natural resources as well as for the provision of tourism and recreational opportunities for the people (Boyd, 2006). Recreational forest used as the conservation of forest areas for recreation, education, and the protection of the unique biodiversity. It is a place designated not only for outdoor activities but also for the conservation of local biodiversity such as flora and fauna as well as areas where environmental education can be operated. However, it is observed that recreation forests are dominantly serving for recreational activities purpose.

Hutan Lipur Sungai Congkak is one of the recreational forests with nature based attraction located in rural area. This has led to the increase of visitors both local and international which needs consistent management to improve the service quality provided by the area. It also contributes threat to the natural resources and the facilities at the recreational area which gives adequacy of service quality from the visitor's viewpoint. Several potential environmental impacts may also arise from tourism, which reduces the natural assets of recreational forest area and causing declining on the service quality. These factors include inappropriate infrastructure development, and various forms of human behaviour that give impact on flora and fauna of the forest area (McNeely et al., 1992). Consequently, the evaluation of service qualities at the forest will be able to entice more people from a wider area to fulfil their 
recreational needs. Thus, a good strategy in developing recreational forests as well as management is necessary to meet the main goal of the development, which is for conservation and activity to gained quality of life.

\subsection{Research Sites and Methodology}

\subsection{The questionnaire}

The questionnaire was used as data collection instrument. Likert scales were used to measure respondent expectation and satisfaction level by using the scales of "Strongly Satisfied $=5$ ", "Satisfied $=4$ ", "Neutral $=3$ ", "Dissatisfied = 2", and Strongly Dissatisfied $=1 "$.

\subsection{Case study area}

This study highlighted a study associated regarding on the expectation and satisfaction towards the chosen case study which was Hutan Lipur Sungai Congkak, Selangor. Hutan Lipur Sungai Congkak Ulu Langat, Selangor is located $21 \mathrm{~km}$ from the town of Jalan Cheras through Hulu Langat - Pangson and $30 \mathrm{~km}$ from Kuala Lumpur. Hutan Lipur Sungai Congkak located in Hulu Langat Forest Reserve which is a part of the Forest State Park also known as the State Heritage Park. This forest is a lowland dipterocarp forest particularly managed by Jabatan Perhutanan Negeri Selangor (JPNS), Tourism Selangor Sendirian Berhad (TSSB) and Majis Perbandaran Selayang (MPS) respectively. Hutan Lipur Sungai Congkak is in rural areas far from urban areas (Tourism Selangor, 2017).

\subsection{Respondents sampling techniques}

According to Krejcie \& Morgan (1970), point out that if the population is 100000 , a sample size of 384 is adequate to support the research findings. Therefore, the research approach was quantitative, and questionnaires were distributed to 384 respondents from different socio-demographic. In selecting the respondent, a simple random technique has been applied where respondents have been chosen based on ready availability on site (Rea \& Parker, 1997) and they all have the potential to be selected as respondent. Respondents have been met face to face and were asked whether agree to become respondent or not. If the respondent agreed, then the survey continued, or else another respondent was selected. Cavaye (1996) stated that collecting data from respondents can be challenging and time-consuming thus effective and efficient data collection requires careful planning and judicious use of both case participants and researcher's time.

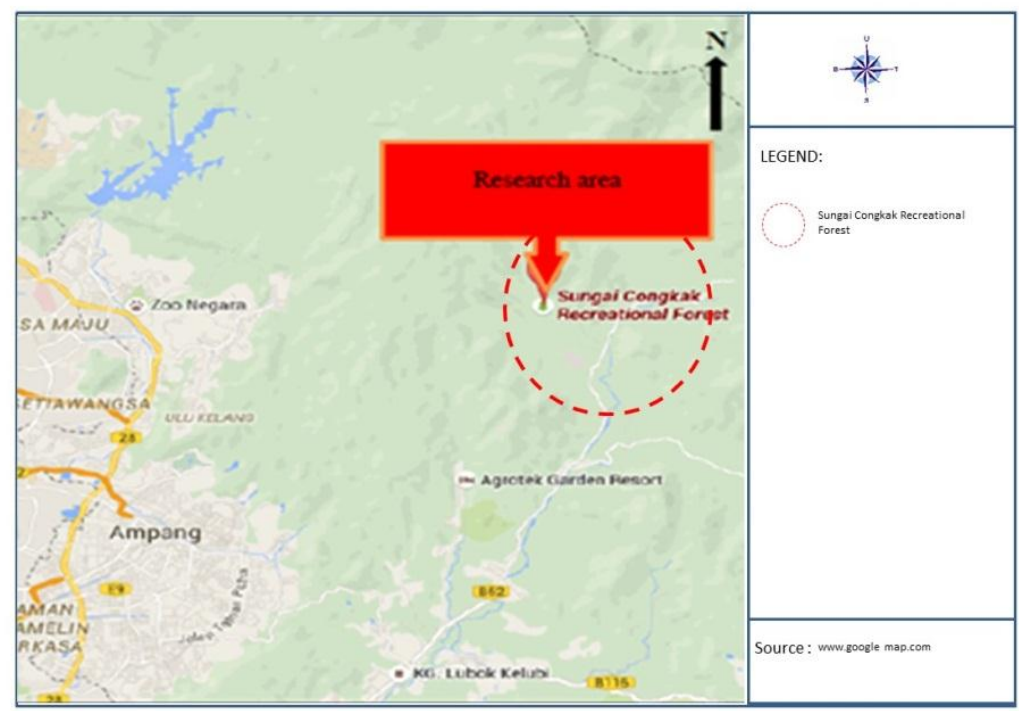

Fig. 2: Study area of Hutan Lipur Sungai Congkak (Source: Google Map, 2017)

\subsection{Discussions}

The purpose of this research is to find out the expectations and satisfactions on service quality among the visitors at Hutan Lipur Sungai Congkak. Services delivered to visitors are necessary to be evaluated from their perspectives, rather than from the management perspective. Service quality is an essential element in every service programme. The aim is to provide high-quality service at the recreational forest and have them to come back again to help increase number of visitors, attract continuous visitors with an increased service quality. This is compelled to provide excellent services to the visitors to have a sustainable competitive advantage. 


\subsection{Demographic characteristics of the respondents}

The sample demographic information is provided in Table 3 and indicates that there were more males $(66.9 \%, n=257)$ than females $(33 \%, n=127)$. The respondents were divided into age groups as follows: from 18 to 24 years $(18.5 \%)$, from $25-34$ years $(45.3 \%)$, from 35 - 44 years $(21.9 \%)$, from $45-54$ years $(10.4 \%)$, from $55-64$ years $(2.6 \%)$ and $65>$ years $(1.3 \%)$. Analysis of the data based on the age of the visitor was mostly among the youth which seldom comes to the forest to engage in recreation activities. The results also show that single $(63.3 \%, n=243)$ were more likely to visit Sungai Congkak than married status $(36.7 \%, n=141)$. In the table present, respondent's race was mostly participated by the Malays with $(66.9 \%, n=257)$ followed by the Indian $(20.1 \%, n=77)$ and Chinese $(13.0 \%, n=50)$. From the total of 384 respondents, majority of the respondents graduated from tertiary education such as diploma, bachelor and master with $(76.8 \%, n=295)$ whereas the remainder graduated from a secondary level of education $(23.3 \%, n=$ 89). Analysis of data on the professions of respondents shows that majority of them were from private sector $(46.4 \%, n=178)$, followed by student $(40.4 \%, n=155)$, government staff $(10.2 \%, n=39)$ and retiree $(3.1 \%, n=12)$.

Table 3. Personal Profile of respondents

\begin{tabular}{cccc}
\hline & Variables & Frequency $(\mathrm{n})$ & Percentage $(\%)$ \\
\hline Gender & Male & 257 & $66.9 \%$ \\
& Female & 127 & $33 \%$ \\
\hline Age & $18-24$ & 71 & 18.5 \\
& $25-34$ & 174 & 45.3 \\
& $35-44$ & 84 & 21.9 \\
& $45-54$ & 40 & 10.4 \\
& $55-64$ & 10 & 2.6 \\
& $65>$ & 5 & 1.3 \\
\hline Marital status & Married & 141 & $36.7 \%$ \\
& Single & 243 & $63.3 \%$ \\
\hline Nationalities & Malay & 257 & 66.9 \\
& Indian & 77 & 20.1 \\
& Chinese & 50 & 13.0 \\
\hline Level of & Secondary Education & 89 & 23.2 \\
Education & Tertiary Education & 295 & 76.8 \\
\hline Professions & Government staff & 39 & 10.2 \\
& Private staff & 178 & 46.4 \\
& Retired & 12 & 3.1 \\
& Student & 155 & 40.4 \\
\hline
\end{tabular}

Table 4 shows the analysis of visitor information for first-time visits. Most of the respondents $(63.5 \%, n=224)$ had experienced visiting Hutan Lipur Sungai Congkak for more than once, meanwhile, $(36.5 \%, n=140)$ were among the first timer visiting the recreational forest. This shows that most respondents were repeater visitors to do recreational activities at Hutan Lipur Sungai Congkak. The frequency visiting time among the respondents were once a month $(27.3 \%, n=105)$, twice a month $(16.4 \%, n=63)$, thrice a month $(19.5 \%, n=75)$ and others was the highest with $(36.7 \%, n=141)$. Others can be considered as respondents visited the area with a different period of frequency. Respondents reported visiting the recreational forests purposes were for relax $(13.8 \%, n=$ $53)$, enjoy facilities $(13.5 \%, n=52)$, picnicking $(13.3 \%, n=51)$, holiday $(12.8 \%, n=49)$, stopover between trips $(9.9 \%, n=38)$, sightseeing $(9.9 \%, n=38)$, enjoy nature $(7.0 \%, n=27)$, recreation and sport $(6.8 \%, n=26)$, and camping $(6.5 \%, n=25)$.

Table 4. Analysis of Visitor Information

\begin{tabular}{llcc}
\hline & Variables & Frequency & Percentage (\%) \\
\hline First Time Visit & Yes & 140 & 36.5 \\
& No & 224 & 63.5 \\
\hline Often Visit & Once a month & 105 & 27.3 \\
& Two times a month & 63 & 16.4 \\
& Three times a month & 75 & 19.5 \\
& Others & 141 & 36.7 \\
\hline Visit Purpose & Recreation and sport & 26 & 6.8 \\
& Relax & 53 & 13.8 \\
& Stopover between trips & 38 & 9.9 \\
& Holiday & 49 & 12.8 \\
& Enjoy facilities & 52 & 13.5 \\
& Picnicking & 51 & 13.3 \\
& Camping & 25 & 6.5 \\
& Sightseeing & 38 & 9.9 \\
& Enjoy nature & 27 & 7.0 \\
& Education & 25 & 6.5 \\
\hline
\end{tabular}

4.2 Identifying the expectation and satisfaction of the service quality

Expectations and satisfactions were both measured using the 5 - point Likert scale whereby the higher numbers indicate a higher level of expectation and satisfaction. The resulted in a negative gap score shows visitors' expectation exceeded the perceived level of 
service demonstrated by the perception scores. This shows an unsatisfactory quality. It is common for visitor's expectation to exceed the actual service perceived and this signifies that there is always need for further improvement. Whereas, equal or higher on the satisfaction level of the service quality indicated that the expectation of visitors was satisfactory in at Hutan Lipur Sungai Congkak.

Overall, it refers on capturing the gap between visitor's expectation and experience which could be either negative or positive. The results were calculated from the satisfaction minus expectation (Satisfaction - Expectation) scores for each item and dimension to identify the service quality gaps. The following analysis used this indicator to determine the difference between the expectation and satisfaction of service quality.

Table 5 shows the result of expectation and satisfaction of service quality at Hutan Lipur Sungai Congkak. Based on the table, the expectation and satisfaction on the five dimension of service quality were analyzed. Analysis of the data on expectation mean for Tangible were (3.76), Reliability (3.67), Assurance (4.03), Responsiveness (4.08) and Empathy (4.03). Meanwhile, results show on satisfaction mean Tangible (3.67), Reliability (3.43), Assurance (4.07), Responsiveness (3.99) and Empathy (4.02). From the outcome, assurance was the only dimension of service quality that achieved a satisfactory level of the service quality. The standard of satisfaction will be obtained when the gap value between the expectation and satisfaction is positive. While, the rest of the four dimensions (Tangible, Reliability, Responsiveness, and empathy) were attained on the unacceptable service quality. Assurance comprised of the ability of the organization and its employees to inspire trust and confidence in what they provide to their customers (Parasuraman et al., 1988).

Table 5. The result of Expectation and satisfaction on service quality

\begin{tabular}{cccc}
\hline Dimension & Expectation Mean & Satisfaction Mean & Gap \\
\hline Tangible & 3.76 & 3.67 & Unacceptable quality \\
Reliability & 3.67 & 3.43 & Unacceptable quality \\
Assurance & 4.03 & 4.07 & Satisfactory quality \\
Responsiveness & 4.08 & 3.99 & Unacceptable quality \\
Empathy & 4.03 & 4.02 & Unacceptable quality \\
\hline
\end{tabular}

\subsection{Analysis of Overall Research Finding}

Level of visitor's satisfaction on the quality of services conducted at Hutan Lipur Sungai Congkak were measured using 23 aspects. SERVQUAL model has been used to assess the degree of satisfaction of visitors and tourists in every component. Table 6 represents the detailed description for each selected dimension of SERVQUAL. Based on the study conducted, results show that visitors' satisfaction is of great importance for today's lifestyle.

Table 6. Service Quality Aspect result

\begin{tabular}{|c|c|c|c|c|}
\hline & $\begin{array}{l}\text { Expectation } \\
\text { mean }\end{array}$ & $\begin{array}{l}\text { Satisfaction } \\
\text { mean }\end{array}$ & ${ }^{*} \mathrm{Gap}$ & $\begin{array}{c}\text { Visitor } \\
\text { Satisfaction }\end{array}$ \\
\hline \multicolumn{5}{|l|}{ Tangible } \\
\hline $\begin{array}{l}\text { Q1 The physical facilities and equipment are } \\
\text { visually aligned and good condition. }\end{array}$ & 4.20 & 4.33 & 0.14 & Satisfied \\
\hline $\begin{array}{l}\text { Q2 Information centre gives relevant information } \\
\text { Q3 Adequate transport systems }\end{array}$ & $\begin{array}{l}3.67 \\
3.31\end{array}$ & $\begin{array}{l}3.68 \\
3.33\end{array}$ & $\begin{array}{c}0.10 \\
0.018\end{array}$ & $\begin{array}{l}\text { Satisfied } \\
\text { Satisfied }\end{array}$ \\
\hline $\begin{array}{l}\text { Q4 Accessibility of physical facilities and natural } \\
\text { resources }\end{array}$ & 3.67 & 3.80 & 0.128 & Satisfied \\
\hline Q5 Neat appearance of the park's staff & 3.33 & 3.36 & 0.31 & Satisfied \\
\hline Q6 Providing adequate waste disposal area & 4.04 & 3.67 & -0.370 & Dissatisfied \\
\hline Q7 Considered needs of disabled & 4.09 & 3.55 & -0.534 & Dissatisfied \\
\hline \multicolumn{5}{|l|}{ Reliability } \\
\hline Q8 Staff providing service with punctual & 4.03 & 3.29 & -0.740 & Dissatisfied \\
\hline $\begin{array}{l}\text { Q9 Staff provide a promptly efficient and timely } \\
\text { Q10 Staff providing accurate and correct } \\
\text { information }\end{array}$ & $\begin{array}{l}3.67 \\
3.31\end{array}$ & $\begin{array}{l}3.68 \\
3.33\end{array}$ & $\begin{array}{c}0.10 \\
0.018\end{array}$ & $\begin{array}{l}\text { Satisfied } \\
\text { Satisfied }\end{array}$ \\
\hline \multicolumn{5}{|l|}{ Assurance } \\
\hline Q11 Providing adequate safety facilities & 4.08 & 4.09 & 0.044 & Satisfied \\
\hline Q12 Tourist feels safe and secure & 3.99 & 4.03 & 0.034 & Satisfied \\
\hline $\begin{array}{l}\text { Q13 The staff is consistently friendly with tourist } \\
\text { Q14 Staff has knowledge to answer question }\end{array}$ & $\begin{array}{l}4.06 \\
4.01\end{array}$ & $\begin{array}{l}4.10 \\
4.04\end{array}$ & $\begin{array}{l}0.039 \\
0.031\end{array}$ & $\begin{array}{l}\text { Satisfied } \\
\text { Satisfied }\end{array}$ \\
\hline \multicolumn{5}{|l|}{ Responsiveness } \\
\hline Q15 Willing to assist tourist in all aspect & 4.04 & 3.70 & -0.333 & Dissatisfied \\
\hline Q16 Staff willing to respond to tourist's curiosity & 4.09 & 4.13 & 0.034 & Satisfied \\
\hline $\begin{array}{l}\text { Q17 Staff inform tourist of the exact services and } \\
\text { products offered }\end{array}$ & 4.10 & 4.13 & 0.029 & Satisfied \\
\hline \multicolumn{5}{|l|}{ Empathy } \\
\hline $\begin{array}{l}\text { Q18 Staff give the tourist personal attention } \\
\text { Q19 Staff understand the tourist specific need }\end{array}$ & $\begin{array}{l}4.08 \\
4.11\end{array}$ & $\begin{array}{l}3.99 \\
3.67\end{array}$ & $\begin{array}{r}-0.089 \\
-0.445\end{array}$ & $\begin{array}{l}\text { Dissatisfied } \\
\text { Dissatisfied }\end{array}$ \\
\hline
\end{tabular}




\begin{tabular}{|c|c|c|c|c|}
\hline $\begin{array}{l}\text { Q20 Convenient location of facilities and } \\
\text { equipment }\end{array}$ & 4.04 & 4.08 & 0.039 & Satisfied \\
\hline Q21 Adequate water supply & 3.74 & 4.04 & 0.302 & Satisfied \\
\hline Q22 Providing praying spaces & 4.07 & 4.11 & 0.042 & Satisfied \\
\hline Q23 Comfortable facilities provided & 4.15 & 4.20 & 0.049 & Satisfied \\
\hline
\end{tabular}

*Gap: Satisfaction mean minus Expectation mean (SM-EM)

Based on the study, there were seven elements in the dimension of Tangible. The result represents that most of the items on Tangible were on the satisfying level. There were five out of seven elements (Q1, Q2, Q3, Q4 and Q5) were satisfied while the two items (Q6 and Q7) were not satisfied. The items that were satisfied comprised of the condition of facilities, information provided, transport system, accessibilities, and staffs appearance. Crucially, the items in waste disposal and needs of disabled were unsatisfied which shows the lack of concern by the management on these aspects. According to Zeithaml et al. (2006), associations should have the capacity to customize services for dealing with their customer's special needs.

On the other hands, the dimension of Reliability indicated three elements (Q8, Q9 and Q10). The element is mainly about the service given by the staff which shows the ability to perform the promised service dependably and accurately (Lovelock et al., 2004) including promptly efficient (Q9) and providing accurate information (Q10). Only Q8 were unsatisfied which represents the punctuality of the staffs.

SERVQUAL research showed Assurance comprised of four elements which focus on the safety of facilities (Q11), visitor safety (Q12), friendly (Q13) and staff knowledge (Q14). This is necessary since assurance is related to management excellence behaviour which will instill confidence in visitors. Moreover, staff must actively attempt to do things correctly the first time to avoid mistakes that can cause time and money (Dorain, 1996). Results show all four elements gained a positive gap score which led to the satisfying level. These proved that the management had provided a guarantee to the visitors. Sudin (2011), stated that satisfaction is understood to be predicted by service quality to increase visitor's satisfaction considering their expectations.

Following dimension is Responsiveness covers three satisfied elements that determine how the staff assist visitors and their willingness to help them provide with prompt service (Q15), respond to tourist problem (Q16) and offer appropriate information on services and products (Q17). It can be observed as the right of the visitors to adequate and timely care. Moreover, staff should make provision for timely services (Parasuraman et al., 1988). Only Q15 attained on the negative gap score displays not satisfy.

Empathy signifies the last dimension of SERVQUAL covers six elements. Ziethaml et al., (2003) stated empathy implies the staffs will pay attention, listen, adapt and be flexible in delivering what the visitors need. Two elements were on the negative gap score, staff attention (Q18) and staff understanding (Q19). Refer to the results in (Table 6); few elements show satisfy level, the location of facilities (Q20), adequate water supply (Q21), praying space (Q22) and contented and comfortable facilities (Q23). However, there is still a need for improvements in few aspects attention and to understand the visitors' needs to meet their requirement efficiently.

\subsection{Conclusion}

Evaluation of visitors' satisfaction is of great importance in today's business world. Thus, visitors' expectations must be met and exceeded to have them to come back and bring others with them. Quality is a significant issue, and the expectations of the visitors must be quantified to be able to measure and improve it. Overall, the results of the empirical study were obtained and analyzed. It shows that majority of the visitor were satisfied with the service quality in this area but still needs further improvement to be informed. Considering the results of the research, it shows that there is a significant relationship between reliability, tangibles, responsiveness, empathy and reliability dimensions and visitors' satisfaction in Hutan Lipur Sungai Congkak. Based on the analysis, six aspects of service quality were not satisfactory according to the views of visitors. However, visitors are satisfied with the quality of services and products provided in the tourist area which will make visitors to revisit Hutan Lipur Sungai Congkak. Therefore, the government and local authority should take account visitor's satisfaction and experience importantly to ensure the effectiveness of development in Hutan Lipur Sungai Congkak. The research study's results are valuable to destination management, tourism organization and business at Hutan Lipur Sungai Congkak in evaluating the level of visitor's satisfaction towards the dimension of its service quality. Therefore, this study suggests that the quality of service quality and visitor value of tourism has a positive impact on the level of satisfaction by enhancing destination facilities destination accessibility and destination attractions. Excellent service can happen if management and staff employ good teamwork, active communication and share ideas on improving service quality at Hutan Lipur Sungai Congkak, which will result in improving visitors' satisfaction in the future.

\section{Acknowledgments}

We would like to thank the Centre of Studies Parks and Amenity Management, Faculty of Architecture, Planning and Surveying, UiTM Shah Alam, Selangor, Malaysia, Nazimi Farhan bin Jasmin who had contributed in the data collection and all the respondents who kindly participated in the questionnaires survey.

\section{References}


Baker, D. A., and J. L. Crompton (2000). "Quality, Satisfaction and Behavioral Intentions." Annals of Tourism Research, 27 (3): $785-804$.

Blose, J.E. and Tankersley, W.B. 2004. Linking dimensions of service quality to original outcomes. Managing Service Quality. 14(1): 75-89.

Boyd, S.W., (2006). The TALC model and its application to national parks. In: The Tourism Area Life Cycle: Applications and modifications, R.W. Butler (Eds.). Channel View Publications, Clevedon, ISBN: 1845410254, pp: 119-138.

Bruhn, M. and Georgi, D. 2006. Services marketing: Managing the service value chain. London: Pearson Education Limited.

Cavaye, A.L.M. (1996). Case study research: a multi-faceted research approach for IS. Information systems journal 6(3): $227-242$.

Dorian, P. (1996). Intensive Customer Care. Sandton: Zebra Press.

FDPM. (2003). Manual Perhutanan 2003 Jilid III. Kuala Lumpur: Forestry Department Peninsular Malaysia.

Google Maps. (2017). Maps of Hutan Lipur Sungai Congkak. Retrieved from https://www.google.com.my/maps/place.

Jamal, A., \& Naser, K., (2002), "Customer satisfaction and retail banking: An assessment of some of the key antecedents of customer satisfaction in retail banking", International Journal of Bank Marketing, 20, 146-160.

Krejcie, R. V., \& Morgan, D. W. (1970). Determining sample size for research activities. Educational and psychological measurement, 30(3), 607-610.

Lovelock, C.H., \& Wirtz, J. (2004). Services Marketing. 5th. Edition. New Jersey: Prentice-Hall.

Man - Su Kang, Hee, Y.S, Sang, K.P (2015). Advanced Science and Technology Letters Vol.101 (Art, Culture, Game, Graphics, Broadcasting and Digital Contents 2015), pp.59-63.

MacKay, K.J., \& Crompton, J.L. (1988). A conceptual model of consumer evaluation of recreation service quality. Leisure Sciences, 7, 41-49.

MacKay, K.J., \& Crompton, J.L. (1990). Measuring the quality of recreation services. Journal of Park and Recreation Administration, 8(3), 47-56.

McNeely, J.A., J.W. Thorsell and H. Ceballos- Lascurain, (1992). Guidelines: Development of National Parks and Protected Areas for Tourism. 1st Edn, World Tourism Organization, UNEP, Paris, ISBN: 9284400260, pp: 53.

Mohammad, Anber and Alhamadani, Shireen. (2011). Service Quality Perspectives and Customer Satisfaction in Commercial Bnaks Working in Jordan", Middle Eastern Finance and Economics, Issue 14, pp $60-74$.

Mohd Kher, H., Saiful Arif, A., Shahrudin, M. I., \& Chamhuri, S. (2009). Issues and the Need of Perception Study for Recreational Forest Landscape Development in Peninsular Malaysia. Proceeding, Universiti Malaysia Terengganu 8th International Annual Symposium on Sustainability Science and Management (UMTAS 2009), page 573-578.

Navaratnaseelan, J.J. and Elangkumaran, P. (2014). "Impact of Service Quality on Customer Satisfaction: A Study on Customers of Commercial Bank of Ceylon PLC Trincomalee District", Faculty of Management and Finance, University of Ruhuna, pp $359-364$.

Parasuraman, A., Zeithaml, V.A. and Berry, L.L. (1985). A conceptual model of service quality and its implications for future research. Journal of Marketing, Vol. 49, pp. $41-50$.

Parasuraman, A., Zeithaml, V. and Berry, L. (1988). SERVQUAL: a multiple-item scale for measuring consumer perceptions of service quality. Journal of Retailing, $64(1), 29-40$.

Rea, L. M., and R. A. Parker. 1997. Designing and Conducting Survey Research: A Comprehensive Guide,

2nd ed. San Francisco, CA: Jossey-Bass Publishers.

Sahney, S., Banwet, D. K., \& Karunes, S., (2006), "An integrated framework for quality in education: Application of quality function deployment, interpretive structural modelling and path analysis", Total Quality Management, 17, 265 - 285.

Schifman, L. G. \& Kanuk, L. L. 2007. Consumer Behavior. New Jersey. Prentice Hall.

Sudin, S. (2011), "How service quality, value and corporate image affect client satisfaction and loyalty", The 2nd International Research Symposium in Service Management Yogyakarta, Indonesia, 26-30 July.

Tourism Selangor, 2017.

Yahha, N.A., (1999). Environmental Settings of Three Recreation Forests and Their Effects on Visitors' Perception. PhD Thesis, Universiti Putra Malaysia.

Yeo, R.K. (2008). Brewing service quality in higher education. Quality assurance in education volume, Vol. 16, No. 3, pp. $266-286$.

Zeithaml, V.A., Berry, L.L. and Parasuraman, A. (1993), "The nature and determinants of customer expectations of service", Journal of the Academy of Marketing Science, Vol. 21, pp. 1-12.

Zeithaml, V.A \& Bitner M.J. (2003). Services Marketing: Integrating customer focus across the firm. 3 Edition. New York: Mcgraw-Hill.

Zeithaml, V.A., Bitner, M.J. and Gremler, D.D. (2006). Services Marketing: Integrating Customer Focus across the Firm. 4th Edition. New York: McGraw- Hill. 